\title{
Non-native fish species in River Odra and Morava basins in the Czech Republic
}

\author{
Bohumír Lojkásek \& Stanislav Lusk
}

\begin{abstract}
Non-native fish species in River Odra and Morava basins in the Czech Republic. - Acta Musei Silesiae Scientiae Naturales Opava (A). - Acta Mus. Siles. Sci. Natur. 67: 81-96, 2018.
\end{abstract}

\begin{abstract}
There has been the assessment of current occurrence and situation of non-native fish species in two hydrological regions - the Upper Odra and Morava river basins. The river basin of Upper Odra is situated in the area of River Odra springs featuring mostly minor streams which are not currently accessible for the migration of fishes from the lower river parts and from the Baltic Sea because of the existence of tens of migration barriers in the area of Poland. There has been actually proved the occurrence of eight non-native fish species the presence of which is, with the exclusions of Carassius gibelio and Pseudorasbora parva, the result of the planned introduction related to the fish management activities. The River Morava basin consists of two parts - the system of the River Morava itself and the entire River Dyje basin. Currently, there are 16 non-native fish species. Apart from the eight species existing also in the Odra river basin, there are also eight other species the existence of which relates to the migration accessibility from the confluence of these two rivers for fishes from the River Danube through the lower part of the River Morava. The species Lepomis gibbosus, Neogobius melanostomus and Proterorhinchus semilunaris were the last ones which have arrived there by themselves. Coregonus maraena and Coregonus peled are bred in fishponds.

The basic part of the non-native fishes' spectrum existing in free waters of the two basins consists of the species which are bred in aquaculture and fishponds (Oncorhyncus mykiss, Salvelinus fontinalis, Ctenopharyngodon idella, Hypophthalmichthys molitrix, and Hypophthalmichthys nobilis). These species, with the exception of Hypophthalmichthys molitrix and Hypophthalmichthys nobilis, introduced also into the fishing grounds and especially Oncorhynchus mykiss and Ctenopharyngodon idella make the important fishes for anglers. Their presence in the waters of the Czech Republic might be considered as beneficial from the economic point of view. From the ecological point of view, the important fact is that they have become very well acclimatised in the local conditions and their natural breeding does not take place and their distribution in water ecosystems, as well as their numbers are fully determined by the management of the Czech Anglers Union. However, Carassius gibelio, Pseudorasbora parva and also Lepomis gibbosus in the River Morava basin have been assessed as distinctly invasive species having more negative impacts on the original ichthyocenosis and biodiversity. Neogobius melanostomus is also potentially dangerous in this basin. In the case of spread of Lepomis gibosus into the River Odra basin, it might become also potentially highly dangerous.
\end{abstract}

Key words: alien fish species, impact, native fish species, River Odra and Morava basins.

\section{Introduction}

Non-native species are considered, together with significant changes in ecosystems and biotopes, as the most important causes endangering the natural biodiversity in freshwater biocenoses. Together with the increasing efforts to maintain the "original" fish fauna biodiversity, the issue of non-native species and their possible impacts on the native species have become a frequent fish-related topic in recent decades. There have been a number of studies related to that topic published around the world (e.g. Ferguson 1990; Allendorf 1991; Cowx 1997; Efford et al. 1997; Welcomme 1988; Bogutskaya \& Naseka 2002; Williamson 1999; Witkowski 2002; Copp et al. 2005; Wolter \& Rohr 2010; Hanel et al. 2011, Grabowska \& Przybylski 2015). The pronounced negative impact on the natural biodiversity has been ascribed especially to non-native species marked "invasive" (Garcia-Berthou 2007). They are just the species dealt with by a number of studies recently (Koščo et al. 2005; Gozlan 2008; 
Gozlan et al. 2010b; Copp et al. 2005; Grabowska \& Przybylski 2015). Similarly, also in conditions of the Czech Republic, there were studies dealing with non-native species progressively published both in the countrywide publications (Adámek \& Kouřil 1996; Lusk et al.1998, 2008, 2010a; Hanel 2003; Šanda 2006; Musil et al. 2010) and in relation to partial river catchments (Lusk et al. 2004, 2009; Lojkásek et al. 2006).

The assessment of impacts by non-native species on native parts of ichthyofauna has been the long-term issue because some perspectives, used for the species assessment, change in time. Some fish species have a direct negative impact not only on fishes, but also on the character of newly populated biotopes, the original food-related and other ecological relations in waters. An important precondition for the negative impact is the full naturalisation of a non-native species in the relevant biocenosis and usually also the spread with significant increases in its numbers. The negative impacts by a non-native species take frequently place in parallel with other aspects influencing native taxa and usually also in biocenoses which are specific for individual regions, river basins or geographical areas. That is the reason why the assignment of the term "invasive" is often the region-related. However, there has been the official list of non-native species recently issued by the European Union which has an important impact within the Union (Commission implementing regulation (EU) 2016/1141). This European list names only two fish species - Pseudorasbora parva and Perccottus glenii. But even this fact suggests that the assessment of negative impacts by non-native fish species relate mostly only to parts of zoogeographic areas.

In the conditions of the Czech Republic, there have been a number of studies published which assess the impacts of non-native fish species and the fact if those species are invasive or not (Lusk \& Lusková 2005; Lusk et al. 2011, 2011a; Hanel \& Lusk 2012).

We present the actual review in this study (2010-2017), possibly also from 1990, listing non-native fish species together with the assessment of their existing economic benefits and the biological situations in ichthyocenoses in the partial Upper Odra catchment and the River Morava basin.

\section{Materials and the methodology}

The review of actually present non-native fish species and the assessment of their existing economic importance and biological situations relates to ichthyocenoses located in the partial Upper Odra River and in the River Morava basin within the scope as described in the part Determination of the river systems.

The data on the spread by individual species in the area of interest have been based on publicised data, results of the authors' knowledge and information by members of the Czech and Moravian Anglers Unions. Also, the information on the economic importance of the fish species of interest has been the result of the assessment of catch reports provided by both Anglers Unions.

\section{Determination of the river systems}

The river systems in the River Odra and Morava basins in the Czech Republic present currently significantly different characteristics, especially when it comes to the area sizes and the migration interconnection with the European hydrographical network. Both basins have not been hydrologically connected in any way.

River Odra drains the area of Northern Moravia and Silesia having the area of $6252 \mathrm{Km}^{2}$. That presents $7.9 \%$ of the area of the Czech Republic. It is in fact the spring area of the River Odra basin, where the river network consists of minor streams. From the ecological point of view, the important fact is that this river part has been inaccessible to fishes from the middle and lower River Odra parts or for anadromous migrants from the Baltic Sea since the middle of the $19^{\text {th }}$ century because of the existence of tens of migration obstacles - mostly weirs (Blachuta \& Kusnierz 1995; Lojkásek \& Lusk 2004).

River Morava basin has got two basic parts - the catchment of the River Morava itself and the River Dyje basin. Both these rivers join at $\mathrm{Km} 70$ of the River Morava and flow further 
as the lower border part of the River Morava to the confluence with the River Danube. The total area of the River Morava basin in the Czech Republic covers $24110 \mathrm{Km}^{2}$ (the River Dyje basin $13419 \mathrm{Km}^{2}$ and the River Morava basin itself $10691 \mathrm{Km}^{2}$ ) and that presents $30.6 \%$ of the area of the country. The Slovak-Austrian section of the River Morava (Km $70-0.0)$ has the basic importance for any changes in the ichthyofauna because there are no obstacles preventing both way free fish movements (Lusk \& Holčík 1998).

\section{Non-native fish species in the legislature by the Czech Republic}

Within the legislature of the Czech Republic, which relates to non-native species, there is mainly the Act No. 114/1992 Coll. on the nature and countryside protection, which says in $\S 5$ (4): "Any planned spreading of a geographically non-native plant or creature species in the country can take place only when permitted by the nature protecting authority". The geographically non-native plant or creature species is the species not making a part of natural communities in the relevant region. Any spreading of geographically non-native organism species into national parks, protected country areas, national nature reserves, and natural reserves is forbidden by this Act. Permissions for the introduction of non-native species into the country are issued by regional authorities. Another regulation presenting the term non-native species is the Act No. 254/2001 Coll., the so-called Water Act, which says in $\S 35$ (3): "Releasing fishes and other non-native water creatures genetically unsuitable and not verified populations of natural species into water flows and water reservoirs without an approval by the relevant water management authority is forbidden". It should be said that this regulation related to the issue of introduction of non-native fish species has not been practically utilised. The unusual and from the biological point of view not sustainable definition of a non-native organism is presented in the Act No. 99/2004 Coll. on the fishing industry in $\S 2$ (s), where the following is said: "A non-native fish or a non-native water organism that is geographically or genetically unsuitable or not verified fish population or water organism existing in the area of an individual fishing locality in the Czech Republic means populations existing for less than three continuous generations".

Exceptions for the introduction of non-native species into fishing grounds are issued by the relevant regional authorities (KU). Considering the existing situation, if the non-native species has been listed in the ground certificate, in the fish management part, the permission by the regional authority is not required. They are usually the species Oncorhynchus mykiss, Salvelnus fontinalis and Ctenopharyngodon idella. When the species in not listed in the certificate (in some cases Ctenopharyngodon idella), the permission for the introduction is required for the relevant ground and for each year. Some other non-native species are introduced by mistake as an addition to varied carp kind fishes. An important factor in the spreading of non-native fishes in the fishpond areas is also each year repeating massive leaks (tens of tons) from fishponds when they are drained (Carassius gibelio, Pseudorasbora parva).

\section{Utilisation of non-native fish species}

Within the conditions existing in the Czech Republic, there have been attempts to randomly introduce or acclimatise about 40 zoogeographically non-native fish species registered. Most of them have been imported willingly because of production reasons (the breeding in an aquaculture or the utilisation of food resources), or for the purpose of widening the species spectrum for angling. A few species have been spread in our country with other species and some arrived thanks to their own migration. The occurrence of species which were only acclimatised depends on the artificial reproduction and the introduction of successfully bred fries. In the case of species that were naturalised and created vital populations, their further spreading took place mostly with the assistance of humans and the consequent introduction into free waters. 
About 15 taxa from a few tens of formerly imported and introduced non-native fishes occur currently permanently in Czech flows. They ate assessed as acclimatised or naturalised (Lusk et al. 2008; 2010a, 2011; Musil et al. 2010).

Tab 1. List of non-native fis species currently present in the basins of the Upper Odra and Moravia in the territory of the Czech Republic (by Barus \& Oliva 1995; Hanel \& Lusk 2005).

\begin{tabular}{|l|l|l|l|}
\hline Species & \multicolumn{1}{|c|}{$\begin{array}{c}\text { Year of 1st } \\
\text { introduction } \\
\text { in CR }\end{array}$} & Uper Odra & \multicolumn{1}{c|}{ Morava } \\
\hline Ameiurus nebulosus & 1890 & Yes & Yes \\
\hline Anguilla anguilla & $?$ & Native & Yes \\
\hline Oncorhynchus mykiss & 1888 & Yes & Yes \\
\hline Salvelinus fontinalis & 1880 & Yes & Yes \\
\hline Coregonus maraena & 1882 & No & Yes \\
\hline Coregonus peled & 1970 & No & Yes \\
\hline Hucho hucho & $?$ & No & Native \\
\hline Ctenopharyngodon idella & 1961 & Yes & Yes \\
\hline Pseudorasbora parva & 1981 & Yes & Yes \\
\hline Carassius gibelio & 1972 & Yes & Yes \\
\hline Hypophthalmichthys molitrix & 1961 & Yes & Yes \\
\hline Hypophthalmichthys nobilis & 1964 & Yes & Yes \\
\hline Gasterosteus aculeatus & 1915 & No & Yes \\
\hline Lepomis gibbosus & 1929 & No & Yes \\
\hline Proterorhinus semilunaris & 1994 & No & Yes \\
\hline Neogobius melanostomus & 2008 & No & Yes \\
\hline
\end{tabular}

The reason behind the occurrence of individual non-native fish species in both assessed hydrological units was the introduction by humans. Some other taxa exist only in the River Morava basin. They spread in the area only by their own activities from the River Danube thanks to the migration accessibility of the lower part of the River Morava as indicated by data in Table 1.

\section{Results}

\section{Ameiurus nebulosus}

It was originally imported for the purpose of breeding and it was consequently introduced into fishponds and free waters in the Czech Republic. It has become naturalised mostly in larger river basins (River Vltava and Labe). Canon (1927) mentioned this species in relation to the River Jihlava basin in the past. In the second half of the $20^{\text {th }}$ century, this species was mentioned in several places in the middle part of the River Morava flow (Veselí, Napajedla, Otrokovice, and Kroměříž - Km 120 to 180). Currently, the permanent occurrence is known in one locality - Medek's fishponds. They are two smaller flooded areas (2.8 hectares) remaining after the former excavation of sand-gravel at the edge of Kroměŕíž area (the information by K. Ivánek). In the River Odra basin, the existence is long-term known in ponds in the locality Gliňoč near Bohumín (the finding by B. Lojkásek in person) and in the pond system in Studénka. The negative impacts by this species on fishes in the original ichthyocenosis include predation, the feeding and the space competition. This species has been assessed within our conditions as invasive (Lusk \& Lusková 2005).

\section{Anguilla anguilla}

This species has been native in the River Odra basin and there are currently artificially bred juvenile individuals put into water flows and water reservoirs. In future, we assume that the eels 
will be put only into rivers in which the safety of downstream migration will be assured at the maximum. The conception of the eel management counts on the Rivers Odra, Olše, Ostravice, Opava and Moravice, which should be equipped in profiles of small water power stations with safety equipment allowing the eel migration for the purpose of reproduction in the Sargasso Sea. It is the current fact that many adult individuals die during their downstream migration because of injuries caused by turbines of water power stations. The species in the River Morava basin is considered as non-native and its occurrence there has been the result of past introductions and even some limited current introductions too.

\section{Oncorhynchus mykiss}

The first imports of this species from Northern America took place for the purpose of extension and enrichment of fish communities in free waters. However, the species has progressively found its use mostly in the intensive aquaculture as the reproduction subject. Currently, there are races bred which have varied origins (imports and the local breeding). Especially at the end of the $20^{\text {th }}$ century and at the beginning of this century, this species has become also an important object of sport angling. It is intensively introduced into the fish grounds when of the angling size and that means its removal by anglers shortly after its introduction. It is mostly considered as the compensation for the significant lowering of catches of the original Salmo trutta. For example, there were 66000 fish - $15388 \mathrm{Kgs}$, of Salmo trutta caught in fish grounds of Moravian Anglers Union in 1990, and 12511 fish - $3576 \mathrm{Kgs}$, of Oncorhynchus mykiss. In 2015, there were caught only 16518 fish - $5179 \mathrm{Kgs,} \mathrm{of} \mathrm{Salmo}$ trutta, but 26995 fish - $10310 \mathrm{Kgs,}$ of Oncorhynchus mykiss.

The issue of competition relations existing between the species Salmo trutta and Oncorhynchus mykiss clearly indicates that the intensive introduction of the non-native species of the angling size into the biotope of Salmo trutta, which has been the characteristic territorial species, is the result of the space and also feeding competitions.

\section{Salvelinus fontinalis}

This species was imported similarly as the rainbow trout to enrich the species composition in fish grounds. It was later utilised mostly in localities featuring water with low $\mathrm{pH}$ values. It was specifically in Jizerské Mts. in the reservoirs Bedřichov, Josefův důl and Souš (Šanda \& Švátora 2002), where vital populations of this species lived for decades. In some other localities, specifically in the reservoirs Morávka and Šance, in the catchment of Upper River Odra, its population existed for a few years before it has disappeared by itself (Lojkásek, his own experience). Considering the low resistance against mechanical injuries and illness, Salvelinus fontinalis occurs now only rarely (Kálal 1987). The existing catches in fish grounds within both assessed regions are the results of random introductions of individuals from artificial breeding grounds.

\section{Coregonus maraena}

This species was imported for the purpose of breeding in fishponds, where, especially in cooler areas, it is still successfully bred. It is occasionally also introduced into some reservoirs in the River Vltava and Labe basins, for example in the water reservoirs Lipno and Pastviny, where short-term reproduction has been observed. In the River Odra basin, there were breeding attempts with Coregonus maraena and hybrids with Coregonus peled organised in fishponds in the $1960 \mathrm{~s}$, but, thanks to the temperature conditions (the higher water temperature), they were unsuccessful. This species was also introduced into some lakes, the results of gravel mining, near Bohumín at the end of the last century (Lojkásek et al. 2006). It happened specifically in the small water reservoir called Sedlinka in the Municipality of Nové Sedlice in the region of Opava, in Stříbrné (Silver) Lake in Opava, and in the small water reservoir Pocheň on the creek 
of Čižina in the region of Krnov. For the Silver Lake locality, which is a flooded gypsum mine, small Coregonus maraena were bred in the 80 s and 90 s of the 20th century in the park of Chateau Radun (the information by M. Kiszka from the Czech Anglers Union). Currently, this species does not occur in the basin of Upper River Odra. This species has been fully acclimatised in the conditions existing in the Czech Republic, but its production in fishponds and any temporary existence in some fish grounds entirely depends on artificial reproduction and breeding. Any successful catches of adult individuals have usually taken place in spring and autumn months. The low return ability of the individuals, thanks to difficult angling, prevented wider utilisation of this species in fish grounds. Any negative impacts on fish communities of autochthonous species by the introduction of individuals of this species are not known.

\section{Coregonus peled}

This species was imported for breeding and fishpond production, where it has been currently successfully utilised. It presents similar demands as Coregonus maraena with which it is successfully crossbred within the artificial reproduction. In the River Odra basin, there have not been any records found about the direct introduction of this species, but it is highly probable that individuals, introduced as Coregonus maraena, were in fact the hybrids with Coregonus peled. The species has fully acclimatised in our conditions, but its occurrence is fully dependent on the artificial reproduction. Occasionally, it is introduced into some water reservoirs, but the efficiency of catches is very low. Sport anglers usually do not differentiate both species of Coregonus. It is bred in fishponds in the basin of River Morava (in the region of Vysočina), but it does not exist in the River Odra basin.

\section{Hucho hucho}

This species is native in the River Morava basin, where it created smaller populations. However, they have disappeared. The existence was, for example, known in the River Bečva catchment, in the reservoir Bystřička in the region of Vsetín, from where 64 fish of this species moved for spawning to a tributary in 1979. Their average length was about $80 \mathrm{~cm}$ (the text and the photo documentation by Pavel Kotrla). Currently, it occurs only sporadically, thanks to the introduction of spawn from artificial breeding (Hanel et al. 2013; Lusk 1976). It is a nonnative species in the River Odra basin and any existence depends on the introduction from the artificial breeding. In the past, it was also introduced into River Moravice (Dyk 1952). Lojkásek (1996) described the existence in the water reservoir Morávka.

This species was introduced also into the water reservoir Šance at the beginning of the 1990s. However, no further data on the existence of adult individuals are known from that locality (Lojkásek, not published yet).

\section{Ctenopharyngodon idella}

The aim of the introduction of this species was its utilisation of the produced higher water plants in fishponds and water reservoirs. Apart from the breeding in fishponds, it has been utilised also in stagnant waters of some fish grounds existing in the River Odra and Morava basins. This species has been fully acclimatised in our conditions, but its existence is fully dependent on the artificial reproduction. Thanks to good meat quality, it has become a popular consumer fish and thanks to easy catches, it has been also an important angling object. The fact that it does not reproduce naturally within our conditions significantly increases its short-term utilisation within conditions requiring the lowering of biomass of the submersed vegetation. The successful utilisation of the species has been known from the 1970s, from the water reservoir Olešná near Frýdek-Místek (Lojkásek, not publicised). Thanks to its ability of putting an efficient eating pressure on water plants, individuals of this species must not be introduced 
in waters within protected areas where the submersed herb vegetation serves as the base for spawning of phytophil fish species.

\section{Pseudorasbora parva}

This species has spread thanks to the introduction of herbivorous fishes from Hungary and the distribution of young fish after 1982. It has spread during few years into most fishpond complexes in the Czech Republic (Jankovský 1983; Wohlgemuth \& Šebela 1987; Lojkásek 1984). Currently, it occurs in fishponds and free waters in both assessed regions. The species is one of the two registered on the list of invasive non-native species having negative impacts on the biodiversity in the European Union. In the conditions existing in the Czech Republic, this species has been already marked as invasive by Lusk \& Lusková (2005).

Its negative impacts on native species have been usually mentioned only in relation to Leucaspius delineatus. Some studies from the area of Western Europe say that the disappearance of Leucaspius delineatus from the original localities has been caused by the illness developed thanks to the microbial pathogen Sphaerothecum destruens, the transmitter of which is Pseudorasbora parva (Gozlan et al. 2005; Carpentier et al. 2007). It is also well known that Pseudorasbora parva in localities with high number populations significantly influences the zooplankton community (Pechar et al. 2017).

The hybridisation between the two species is also known. In the conditions existing in the Czech Republic, the main areas of existence of Leucaspius delineatus are smaller ponds usually drained after 3-4 years. Leucaspius delineatus practically disappeared from these source localities after their intensive utilisation, including every year draining in 1960-1980, even without the presence of individuals of Pseudorasbora parva. In our conditions, both species occur in some localities together, for example, in stagnant branches in the area of the confluence of the Rivers Morava and Dyje (Lusková et al. 2002).

\section{Carassius gibelio}

The summary name of Carassius gibelio covers in nature also other forms marked now as independent species (Carassiu auratus, Carassiu langsdorfi), which are impossible to visually differentiate within the field conditions.

Carassiu gibelio is a good example of the subject which, relatively within a short-term (the first occurrence recorded in the River Morava basin in 1976, Lusk at al. (1977)) settled in most suitable waters in the Czech Republic by its own migration but also by active human contribution (Lusk et al. 1998a; Lusková et al. 2010). It has created stable and frequently high number populations in most newly settled localities. In the course of first years after the finding about the existence of this species in our waters, most caught individuals were triploid females reproducing gynogenetically. Progressively, diploid males and females also occurred in individual populations and the current existence of triploid fish (females) and diploid individuals (males and females) highly varies. Bigger individuals have become objects of sport angling in fish grounds. Carassiu gibelio is highly negative in fisheries because it consumes a large part of fishpond production (the zooplankton) to the detriment of bred carps. The production of Carassiu gibelio from fishponds is utilised by consumers only rarely (Lusk 1986, 2010; Lusková et al. 2002). A part of the production from fishpond systems existing in the River Odra basin has been utilised by the Vietnamese community and Polish traders (Lojkásek, not published yet).

This taxon has proved to be the most significant invasive species within the conditions of the Czech Republic, especially in relation to the native ichthyofauna. Against other species, it is mostly a strong feeding and space competitor. The triploid females also create a high pressure on males of other species by their sexual parasitism. That has been proved within a larger scale in the case of carp species like, for example, Carassiu carassius, Cyprinus carpio, Tinca tinca, 
Abramis brama, and Rutilus rutilus (Lusková et al. 2004).

Carassius gibelio thus significantly participates, thanks to its biological features, in the disappearance of the native Carassius carassius with which it creates also interspecies hybrids (Papoušek et al. 2008).

\section{Hypophthalmichthys molitrix}

This species has been acclimatised in the conditions of the Czech Republic and it has become the object of breeding in fishponds within the River Morava and Upper Odra basins. Its existence depends on the artificial reproduction (e.g., the Pohořelice Fishery Ltd.) and the production of spawn. It is introduced into fish grounds only unofficially and rarely. It is randomly caught there by sport anglers together with Hypophthalimichtys nobilis. Anglers do not differentiate between these two species (Table 2). It is bred in fishpond areas within both regions of interest only very seldom.

\section{Hypophthalmichthys nobilis}

This species has been acclimatised and it is bred in fishponds within the basins of Rivers Upper Odra and Morava. In breeding, it is preferred, thanks to its better resistance during pond fishing to Hypophthalimichtys molitrix. Under our conditions, its existence also completely depends on the artificial breeding. It gets into water flows only randomly and it is sporadically caught by sport anglers. Occasional abundant occurrences were found in the flow of the River Dyje below the Novomlýnská reservoir from which it escapes during high water flows. There was an exceptional situation at the beginning of July 2009, when schools of large individuals of Hypophthalichthys species and Ctenopharyngodon idella occurred in the River Dyje, below the step in Břeclav. They were probably spawning migration from the River Danube (Lusk et al. 2009).

\section{Gasterosteus aculeatus}

The pronounced and mostly temporary occurrences of the species are the result of its introductions from aquaria breeding. Wohlgemut (1989) described the existence of Gasterosteus aculeatus in the basin of the River Morava near Brno and in the catchment of the River Jihlava. Currently, it exists near Brno in Holásecké Lakes and in the Černovický Creek. They are 10 small lakes in the total. They are mostly the reminders of an old River Svitava branch. Hanel (2003) mentions its existence in the Upper Odra basin without any precise locality. Currently, this given species is unknown in free waters there.

\section{Lepomis gibbosus}

The sporadic existence of Lepomis gibbosus in the area of the lower flows of the Rivers Morava and Dyje has been mentioned historically. Originally, the species existed in separated places usually thanks to transfers of fish spawn and the focussed introduction. We have recorded the occurrence of this species in the area of the confluence of the Rivers Morava and Dyje progressively since 1997 (Lusk et al. 2002, 2009, the not publicised results). Currently, the frequency of the species has significantly increased and in some places it creates even stable large number populations. The spreading of this species in the area of the confluence of the Rivers Morava and Dyje has been the result of migration from the area of lower parts of the River Morava where it has spread after 2010. Nevertheless, the current spreading into other localities takes place also thanks to significant human contributions (J. Tomeček, the information in person). The human share in the species spreading is supported by the sporadic occurrence of Lepomis gibbosus in the catchment of River Svratka (L. Vetešník, the information in person). The spreading of this species is probably also assisted by higher temperatures and recent mild winters. In the Upper Odra basin, there are only data on 
the introduction and about observations of several tens of individuals known in breeding fishponds owned by the Czech Anglers Union in Krnov and Lichnov in 2006 (Bohumil Ramach, the information in person). Considering the original ichthyocenosis community, the fact that the individuals of this species seem aggressive to other fishes is important. That happens thanks to their pronounced territorial behaviour and thanks to the fact that they use fries of other species.

\section{Proterorhinus semilunaris}

In Slovakia, this species has been known in the inlet of the River Morava into River Danube since the $19^{\text {th }}$ century (Koelbel 1874). It was originally called Proterorhinus marmoratus. Its existence in the Czech Republic has been most probably the result of introductions by humans (Novomlýnské reservoirs, River Dyje above the Vranov reservoir). Consequently, after its reproduction, the extensive spreading has taken place in the area. The species accessed by migration only the area of confluence of the Rivers Morava and Dyje from the lower parts of the River Morava above the inlet to the River Danube. That has been proved by findings in the Morava flow and in tributaries (Spidler et al. 1992).

The first finding in waters of the Czech Republic took place in 1994, when the species was found in the Mušov reservoir (Lusk \& Halačka 1995). In consequent years, it settled also in the Věstonická and Novomlýnská reservoirs. It started its progressive spreading by both migrations into the River Dyje, below the Novomlýnská reservoir, and to the River Dyje upstream from the Mušov reservoir and to the Rivers Jihlava and Svratka. In parallel, the spreading of the species was recorded from the confluence of the Rivers Morava and Danube in the direction upstream in the River Morava. The species occurs currently in the River Morava, from the confluence with the river Dyje (Km 70) to the step in Hodonín (Km 101.8). In the River Dyje, the existence is known from the inlet to the River Morava in the direction upstream, including the three reservoirs within the water works Nové Mlýny and farther upstream to Znojmo. It exists also in the short section of the River Dyje (Km 200-209.5) at the border with Austria above the Vranov reservoir (Lusk et al. 2000). The species is currently fully naturalised and quite abundant even in the tributaries Kyjovka, Jevišovka, Svratka, and Jihlava (Prášek \& Jurajda 2005, other not publicised results).

\section{Neogobius melanostomus}

This species exists only in the basin of the River Morava, in the lower parts of the Morava and Dyje flows above their confluence. Its existence has been the result of natural migration through the lower section of the River Morava from the River Danube. The first records of its occurrence are from 2008 (Lusk et al. 2008). It has currently settled in the lower Morava flow, above the confluence with the River Dyje (Km 70) to Hodonín (Km 101.8), and in the Dyje flow, from the confluence with the River Morava to the dam of Novomlýnská reservoir (Km 46). It creates high number populations, when the conditions are favourable (the enforcement of banks and steps with stones). The species is spreading very fast, but it is prevented so far by insuperable migration barriers like the weir in the River Morava in Hodonín and the dam of the Novomlýnská reservoir in the River Dyje. We might assume that individuals of this species are strong feeding and space competitors for fishes of the original communities, especially in localities with their abundant occurrence. The species belongs to the species which have spread both in Europe and Northern America (Gido \& Brown 1999) during last decades thanks to the artificial connections of river channel systems and the transport by ships. A good example is the unique and locally isolated occurrence in the flow of the River Labe at Ustí n. Labem in 2015, while the first documented occurrence of this species was known in 2013 in the River Elbe (Labe) close to Hamburg, i.e., $600 \mathrm{Km}$ lower. There is the assumption that such transfer was possibly only by the ship transport (Roche et al. 2015). 
The basic part of the species composition of the non-native species in the basins of the Rivers Morava and Odra consists of the taxa which were or have been bred and their individuals of varied age were consequently introduced into free waters. The situation in the Upper Odra basin has been stable for a number of years because the river system is inaccessible to fishes from the middle and lower sections of the River Odra, thanks to the fragmentation of the water environment by gravity objects. The species composition is currently similar as described already by Lojkásek et al. (2006). Currently, there has been the existence of 8 non-native species proved. They originate from other zoogeographical areas (Table 1). Newly, there has been the existence of Ameiurus nebulosus proved, but that might be its isolated occurrence lasting for decades. The existence and the numbers of Oncorhynchus mykiss, Salvelinus fontinalis and Ctenopharyngodon idella depend on the focussed introduction within the framework of fish grounds management, where they make objects for anglers.

There has been currently the existence of 16 non-native species (Table 1) proved in the basin of the River Morava. There is the identical spectrum of 8 species as in the basin of the River Odra. A part of the basin, at the confluence of the Rivers Morava and Dyje, is freely accessible to the fish migration from the lower parts of the River Morava and possibly also from the River Danube. That had allowed the natural spread of Carassius gibelio in the past and recently also of Lepomis gibbosus and Neogobius melanostomus from Slovakia. Carassius gibelio, Pseudorasbora parva and newly also the spreading species Lepomis gibbosus and Neogobius melanostomus have been assessed in a long-term as the invasive species existing in the River Morava basin. The existence of the two new species has been limited so far to the lower flows of the Rivers Dyje and Morava, above their confluence, while the further spread upstream has been so far prevented by hydro-technical constructions. However, we cannot exclude their further spreading within both river basins caused by humans like it happened in the past with Carassius gibelio and Protherorhinus semilunaris.

\section{Production importance of non-native species in free waters}

In the case of fish grounds, where some non-native species were willingly introduced, with the exception of Carassius gibelio complex, the taxa are fully acclimatised but not permanently naturalised (see Table 2).

Tab 2. Catches of non-native fish species by anglers in the basins of the Rivers Morava and Upper Odra in the territory of the Czech Republic.

\begin{tabular}{|l|l|c|c|c|c|}
\hline Species/ year & & $\mathbf{2 0 0 0}$ & $\mathbf{2 0 0 5}$ & $\mathbf{2 0 1 0}$ & $\mathbf{2 0 1 5}$ \\
\hline Oncorhynchus mykiss & $\mathrm{n}$ & 49318 & 62543 & 62634 & 61001 \\
& $\mathrm{Kg}$ & 15349 & 21200 & 22621 & 22614 \\
\hline Salvelinus fontinalis & $\mathrm{n}$ & 1665 & 3405 & 4522 & 4069 \\
& $\mathrm{Kg}$ & 605 & 1097 & 1429 & 1481 \\
\hline Ctenopharyngodon idella & $\mathrm{n}$ & 7777 & 10573 & 10484 & 10968 \\
& $\mathrm{Kg}$ & 29145 & 37094 & 30128 & 37872 \\
\hline Carassius gibelio & $\mathrm{n}$ & 52292 & 22655 & 21851 & 27020 \\
& $\mathrm{Kg}$ & 22856 & 12820 & 9056 & 11578 \\
\hline Hypophthalmichthys sp. & $\mathrm{n}$ & 555 & 922 & 603 & 900 \\
& $\mathrm{Kg}$ & 4317 & 7612 & 6118 & 7627 \\
\hline Coregonus sp. & $\mathrm{n}$ & 278 & 118 & 175 & 7 \\
& $\mathrm{Kg}$ & 179 & 63 & 77 & 6 \\
\hline Total catches of non-native species & $\mathrm{Kg}$ & 72451 & 79886 & 69429 & 81198 \\
\hline Share of non-native fishes in the total catches & $\mathrm{\%}$ & 4.03 & 5.44 & 4.93 & 5.67 \\
\hline Total catches of all species & $\mathrm{Kg}$ & 1797430 & 1467813 & 1407487 & 1432827 \\
\hline
\end{tabular}


Their existence is fully dependent on the human will and on their utilisation for angling sport. We should not have any basic objections to that. However, we must always individually assess the possible negative impacts by the introduction on the original biocenoses in specific localities. The share of non-native species in the total anglers' fish catches in the basins of Rivers Morava and Odra varies on average between 5-6\% (see Table 2). However, if a significant part of this total fish catches in the Czech Republic belongs to Cyprinus carpio (75$80 \%$ ), it becomes clear that the the importance of non-native fish for sport fishing is considerable and of the total catch of fish outside Cyprinus carpio is about $25 \%$.

In fish grounds, Onchorhynchus mykiss specifically often and mostly replaces Salmo trutta in salmon waters and Ctenopharyngodon idella has become a welcome fish to anglers angling in carp waters. From the ecological point of view, the important advantage of both mentioned species is the fact that they do not reproduce naturally in our conditions and their numbers and biomass might be thus regulated within a short-term - in the case of rainbow trout within months, while in the case of grass carp within few years.

\section{Discussion}

Among the non-native fish species, the so-called invasive species are generally considered as absolutely undesirable and threatening the original biodiversity. Basically, they are the species which, thanks to their morphological and genetic characteristics and ecological abilities, managed the full naturalisation and which have the high invasive potential. They quickly assure themselves the high percentage of dominance, numbers and biomass in newly occupied biotope (Coop \& Fox 2007). There is the question which impacts by a non-native species could be considered as satisfactory for marking it as the invasive species. In reality, most non-native species present themselves as feeding competitors to the native species. Another negative impact at the genetic level is clear in the case of Carassius gibelio, at the level of population in the case of Pseudorasbora parva, and at the level of possible changes in the character of the biotope and consequently also the biocenosis in the case of Ctenopharyngodon idella. Within the Czech Republic, Carassius gibelio (complex), Pseudorasbora parva, Ameiurus nebulosus, and Lepomis gibossus are considered as the invasive species, while Neogobius melanostomus is marked as the conditionally invasive species (Lusk et al. 2011, 2011a).

A specific study defining non-native species of plants and animals in the Czech Republic was prepared by Pergl et al. (2016). They have opted for a specific approach, when assessing the invasive risks of the non-native species, based on the complex utilisation of varied view points. Within the so-called Black List, they determined three categories, according to a number of parameters like, for example, the impacts on the natural environment, the population characteristics, management, etc. There have been 6 fish species, which occur in our country, put on the Black List (BL) Cat. 2: Ctenopharyngodon idella, Hypophthalichthys molitrix, Hypophthalichthys nobilis, Micropterus salmoides, Oncorhynchus mykiss and Salvelinus fontinalis. The Category 3 within the Black List covers 6 species: Ameirus melas, Carassius gibelio, Carassius langsdorfii, Lepomis gibbosus, Neogobius melanostomus, and Pseudorasbora parva. The so-called Grey List includes 1 species: Ameirus nebulosus. There are 11 species on the so-called Watch List. They all exist in neighbouring countries. A more detailed review of the individual species, from the point of view of the conditions within the hydrological network of the Czech Republic and the utilised forms of the fishing industry (the fishponds, the intensive aquaculture, and the sport angling) suggests that the used approach has not been usable for the actual situation without reservations. For example, the taxa listed in BL 2 are the species the existence of which, including their numbers in natural ecosystems, is currently well managed and regulated by humans within their fish management activities. On the other hand, we cannot exclude that the actual trend of rising water temperatures might change the situation so much that the originally Asian species would start reproducing naturally 
even in our conditions and their numbers could increase independently from us similarly as it currently happens with Carassius gibelio and others.

However, there might be important changes taking place in the population numbers and in the metapopulations of non-native species in time. In the result of that there could be the lowering of intensity of the feeding and space competition, the limitation of the occurring areas and thus the limitation of the total negative impacts on the biodiversity of the affected biocenoses. We might present as an example, within the conditions existing in the Czech Republic, Ameiurus nebulosus. This species had created a very strong population in the middle part of the River Labe and in its lower parts in the mid of the $20^{\text {th }}$ century. It had even become an important object for anglers. For example, there were reported catches of 62083 fish in 1952 and even 65804 fish in 1957. Currently, there are only hundreds of fish caught in the identical area.

Within EU, there are only two species on the list of invasive species having the Europe wide validity - Pseudorasbora parva and Perccottus glenii. This is the result of the fact that the invasive impacts - thus the significant negative impact on the original biodiversity, is mainly the regional issue in Europe (Grabowska \& Przibylski 2015) P. parva has been the generally spread species and the idea of possible limits in its numbers, or of its occurrence areas seem to be just theoretical. Also, the negative utilisation for the diversity of the original biocenoses is, up to a certain level, local and highly probably specific for the geographical latitude. Percotus glenii makes a classic example of a non-native invasive species which is successful after its translocation from the River Amur basin to the European part of Russia (1912) as it has progressively settled in European river systems. The basic moves of Percotus glenii across river systems was made by humans usually as the not desired addition to transfers of other fish species. Its occupational spreading followed the naturalisation in a suitable part of the water ecosystem (Koščo et al. 2003; Rešetnikov 2004; Lusk et al. 2016). The listing of both taxa on the list of undesired species in EU waters might be a notice of a possible threat, but the placing on the list is, for its numbers and spread into further biotopes in water ecosystems, only a formal legislative act. This situation is confirmed also by the existence of Percotus glenii in Germany (Nehring \& Steinhof 2015), where the doubts in relation to the realistic possibilities for the prevention of the spreading prevail.

\section{Conclusions}

The fundamental role in the undesired spreading of non-native fish species belongs to humans and their both legal and undesirable activities related to hydrological systems. Apart from the imports for introductions and the planned introductions of non-native fish species, there is also a frequent spreading with species which are zoogeographically original. Interconnections of the formerly separated hydrological systems by water channels and by ship transport also present a very fundamental negative anthropogenic factor into water ecosystems. The prevention of spreading of not desired non-native fish species from natural ecosystems, in which vital populations are living, is practically impossible.

We might consider as realistic only a certain reduction in their numbers.

Based on my own long-term knowledge and on the assessment of the actual bibliographic information, we might say that the most efficient limiting factor related to the negative impacts caused by invasive species on the original biodiversity is the exclusion of all forms of introduction. Currently we do not know any example of a successful targeted limitation or removal of a non-native species which has been fully naturalised in the natural ecosystem. The actual "Black Lists", considering the regional negative impacts caused by non-native species on the native biodiversity, seem very important, even if taking into consideration the variable timing of the intensity of those impacts. They are also very important from the information point of view as well as the materials for the implementation of efficient provisions. 
However, they must be prepared on the basis of specific and actual knowledge from the relevant region and they should be actualised within appropriate time intervals (10 years at the maximum). For example, in the case of the basin of Upper Odra, the relations to the existing trend of permanent water and air temperature increases suggest that Lepomis gibosus could become in future just another species having the invasive potential in lower river sections.

Acknowledgements: We wish to acknowledge workers of the Czech and Moravian Anglers Union for the provision of data on the fish introductions into fish grounds and for the registers of fish catches.

\section{References}

Adámek Z. \& Kouřil J. (1996): Nepůvodní druhy ryb posledních let v České republice z hlediska původní ichtyofauny (Alien fish species in the Czech Republic in recent years from the native ichthyofauna point of view) - Biodiverzita ichtyofauny ČR (I): 34-41.

Allendorf F.W. (1991): Ecological and genetic effects of fish introductions: synthesis and recommendations Can. J. Fish Aquat. Sci. 48 (Suppl. 1): 178-181.

Baruš V. \& Oliva O. (eds) (1995): Mihulovci, Petromysontes a ryby, Osteichthyes (1) a (2). Fauna ČR a SR, Academia Praha, sv.28/1 a 28/2, $624+628$ pp.

Blachuta J. \& Kusnierz J. (1995): Odra jako korytarz ekologiczny - analýza ichtyofaunystycna. In: Jankowski K. \& Swierlos z (red): Odra jako korytarz ekologicny. Stan, funcjonowanie, zagroženia. IUCNPoland, Warszawa: 100-115.

Bogutskaya N.G. \& Naseka A.M. (2002): An overview of nonindigenous fishes in inland waters of Russia. Proc. Zool. Inst., Russ. Acad. Sci. 296: 21-30.

Canon H. (1927): Tiere der Heimat. Ein Beitrag zur Tiergeographie des böhmisch-mährischen Höhenzuges. Jihlava, $189 \mathrm{pp}$.

Carpentier A., Gozlan R.E., Cucheriusset J., Pailisson J.M. \& Marion L. (2007): Is topmouth gudgeon Pseudorasbora parva responsible for the decline in sunbleak Leucaspius delineatus populations? - J. Fish Biol. 71: 274-278.

Copp G.H., Bianco P.G., Bogutskaya N.G., et al. (2005): To be, or not to be, a non-native freshwater fish? J. Appl. Ichtyol. 24: 242-262.

Cowx I.G. (1997): Introduction of fish species into European fresh waters. Economic successes or ecological disasters? - Bull. Franc. Peche et Piscicul. 344-345: 57-77.

Dyk V. (1952): Současný výskyt ryb v řece Moravice (The current fish occurrences in River Moravice). - Příloha př́rodověd. sborníku Ostravského kraje 13 (3-4): 1-24.

Efford I.E., Garcia C.M. \& Wiliams J. D. (1997): Facing the challenges invasive alien species in North America. - Global Biodiversity 7: 25-30.

Ferguson M.M. (1990): The genetic impact of introduced fishes on native species. - Can. J. Zool. 68: 10531057.

Garcia-Berthou E. (2007): The characteristics of invasive fishes: what has been learned so far? - J. Fish Biol. 71 (Suppl. D): 33-55.

Gido K.B. \& Brown J. H. (1999): Invasion of North American drainages by alien fish species. - Freshwater Biology 42: 387-399.

Gozlan R.E., St. Hilaire, Feist S., Martin S.W. \& Kent M.I. (2005): Disease threat to European fish. Nature 435: 1046.

Gozlan R.E. 2008. Introduction of non native freshwater fish: is it all bad? Fish and Fisheries 9:106-115.

Gozlan R.E., Britton J.R., Cowx I. \& Coop G.H. (2010a): Current knowlwdge on non native freshwatter fish introductions. - Journal of Fish Biology 76: 751-786.

Gozlan R.E., Andreou D., Asaeda T., et al. (2010b): Pan-continental invasion of Pseudorasbora parva: towards a better understanding of freschwater fish invasions. - Fish and Fisheries 11:315-340.

Grabowska J. \& Przybylski M. (2015): Life-history traits of non-native freshwater fish invaders differentiate them from natives in the Central European bioregion. - Rev Fish Fish Biol 25: 165.

Hanel L. (2003): Komentovaný přehled mihulí a ryb České republiky (Commented review of lampreys and fishes in the Czech Republic) - Bull. Lampetra V, ZO ČSOP Vlašim: 27-67.

Hanel L. \& Lusk S. 2005:Ryby a mihule České republiky. Rozšíření a ochrana. ZOČSOP Vlašim, 447 pp.

- (2012): Biodiverzita ichtyofauny. In: Machar I., Drobilová L. (ed): Ochrana př́rody a krajiny v České republice. Vybrané aktuální problémy a možnosti jejich řešení (Nature and countryside protection in the Czech Republic. Actual selected issues and chances for thein resolve) Univerzita Palackého Olomouc, pp. 639-650. 
Hanel L., Lusk S. \& Andreska J. (2013): Huchen in the Czech Republic: A review. - Arch. Pol. Fish. 21: 143154.

Hanel L., Plesník J., Andreska J., Lusk S., Novák J. \& Plíštil J. (2011): Alien fishes in European waters. - Bull. Lampetra VII, ZO ČSOP Vlašim: 148-185.

Jankovský P. (1983): Výskyt střevličky východní v ČSR (Occurrences of Pseudorasbora parva in Czechoslovakia) - Rybářství, č. 3: 52.

Kálal L. (1987): Introdukce lososovitých ryb do Československa (Introduction of salmon fishes in Czechoslovakia) - Sb. Perspektivní druhy ryb pro ČSSR (Perspective fis species for Czechoslovakia), VÚRH Vodňany, pp. 40-47.

Koelbel C. (1874): Über die Identität des Gobius semilunaris Heck. und G. rubromaculatus Kriesch mit G. marmoratus Pallas. - Verh. Zzo.-bot. Ges. Wien 24: 569-574.

Koščo J., Lusk S., Halačka K. \& Lusková V. (2003): The expansion and occurrence of the Amur sleeper (Perccottus glenii) in Eastern Slovakia. - Folia Zool. 52: 329-336.

Koščo J., Lusk S., Košuthová L., Lusková V., Košuth P. \& Halačka K. (2005): Invázne druhy rýb Slovenska - ich rozšírenie a vplyv (Invasive fis species in Slovakia - their spread and impacts) - Sb. referátů z VIII. České ichtyologické konference, Brno, pp.109-115.

Lojkásek B. (1984): Střevlička východní na Karvinsku (Pseudorasbora parva in the region of Karviná) Rybářství, č. 11: 253.

- (1996): Vývoj druhové diverzity ichtyocenózy v údolní nádrži Morávka v průběhu 30 let (Development in the species diversity in the ichthyocenosis of the Morávka reservoir during 30 years) - Biodiverzita ichtyofauny ČR (I): 50-56.

Lojkásek B. \& Lusk S. (2004): Ichtiofauna dorzecza górnego biegu Odry na terenie republiki Czeskiej. - Arch. Pol. Fish. 12 (Supl. 2): 73-89.

Lojkásek B., Lusk S. \& Papoušek I. (2006): Nepůvodní druhy ryb povodí Odry na Moravě a ve Slezsku (Nonnative fis species in the basin of River Odra in Moravia and Silesia) - Biodiverzita ichtyofauny ČR (VI): 7986.

Lusk S. (1986): The areas of occurrence of giebel carp (Carassius auratus) under Czechoslovak conditions. Živočišná výroba 31: 945-951.

- (2010): Lednická karasí odysea (Odyssey of Carassius in Lednice) - Rybářství č. 8: 40-42.

Lusk S., Baruš V. \& Veselý V. (1977): On the occurrence of Carassius auratus in the Morava River drainage area. - Folia Zool. 24: 377-381.

Lusk S. \& Halačka K. (1995): The first finding of the tubenose goby, Proterorhinus marmoratus, in the Czech Republic. - Folia Zool. 44: 90-92.

Lusk S. \& Holčík J. (1998): Význam bezbariérového spojení říčního systému Moravy a Dyje na území České republiky s Dunajem (Importace of the barrierfree connection of the systém of Morava and Dyje Rivers with the River Danube). - Biodiverzita ichtyofauny ČR (II): 69-83.

Lusk S., Koščo J., Lusková V., Halačka K. \& Košuth P. (2004): Alien fish species in the floodplains in the Dyje and the Bodrog rivers. - Ecohydrology \& Hydrobiology 4(2): 199-205.

Lusk S., Koščo J., Lusková V., Halačka K., Mendel J. \& Košuth P. (2017): The nonindigenous fish Perccottus glenii in the Tisza Rievr drainage, eastern Slovakia - I. part: history of invasion, habitat associations and genetic characteristic (the results up to the year 2006). - Bull. Lampetra VIII, ZO ČSOP Vlašim: 127-143.

Lusk S., Lojkás ek B. \& Lusková V. (2009): Nepůvodní druhy ryb v ichtyocenózách řek Dyje a Odry v úsecích s vyvinutým záplavovým územím (Alien fis species in the ichthyocenoses of Dyje and Odra Rivers in the sections of developer flood areas). - Sb. Říční krajina 6, Olomouc, pp. 93-99.

Lusk S. \& Lusková V. (2005): Invazivní druhy ryb v podmínkách České republiky (Invasive fis species under conditions in the Czech Republic) - Sb. referátů z VIII. České ichtyologické konference, Brno, pp. 116-121.

Lusk S., Lusková V. \& Halačka K. (1998): Introdukované druhy ryb v ichtyofauně České republiky (Introduces fis species in the Czech Republic ichthyofauna). - Bull. Lampetra III, ZO ČSOP Vlašim, pp. 119133.

- (1998a): Karas stř́břitý - 25 let od jeho přirozené introdukce (Carassius gibelio - 25 years of its natural introduction). - Sb. referátů z III. České ichtyol. konf. Vodňany, pp. 135-140.

Lusk S., Lusková V., Halačka K. \& Lojkásek B. (2000): Změny v druhové skladbě ichtyofauny na území České republiky po roce 1990 (Changes in the species composition of Czech Republic ichthyofauna after 1990). - Biodiverzita ichtyofauny ČR (III): 21-28.

Lusk S., Lusková V. \& Hanel L. (2008): Nepůvodní druhy ryb v ichtyofauně České republiky - jejich vliv a význam (Non-native fis species in the Czech republic ichthyofauna - thein impacts and importace). Biodiverzita ichtyofauny ČR (VII): 96-113.

- (2010): The list of alien species in the ichthyofauna of the Czech Republic. - Russian Journal of Biological Invasions 1 (3): 162-175. 
- (2010a): Aliens species in the Czech Republic and their impact on the native fish fauna. - Folia Zool. 59: 57-72.

- (2011). Černý seznam nepůvodních invazivních druhů ryb České republiky (Black List with non-native invasive fis species in the Czech Republic). - Biodiverzita ichtyofauny ČR (VIII): 79-97.

- (2011a): Nepůvodní druhy ryb - můžeme je zastavit nebo alespoň omezit? (Alien fis species - Can we stop or reduce it?). - Sb. z konference „Říční krajina 7“, Olomouc, pp. 103-109.

Lusk S., Lusková V., Halačka K. \& Horák V. (2002): Osteichthyes. - Folia Fac. Sci. Nat. Univ. Masarykianae Brunensis, Biologia 106: 29-49.

Lusk S., Vetešník L., Halačka K., Lusková V., Pekárik L. \& Tomeček J. (2008): První záznam o průniku hlaváče černoústého Neogobius (Apollonia) melanostomus do oblasti soutoku Moravy a Dyje (Česká republika) (The first records of the entry of Neogobius (Apollonia) melanostomus into the area of the Rivers Morava and Dyje influence (Czech Republic)). - Biodiverzita ichtyofauny ČR (VII): 114-117.

Lusková V., Halačka K., Vetešník L. \& Lusk S. (2004): Changes of ploidy and sexuality status of the „Carassius auratus“ populations in the drainage area of the River Dyje (Czech Republic). - Ecohydrology \& Hydrobiology 4 No. 2: 165-171.

Lusková V., Lusk S., Halačka K. \& Vetešník L. (2010): Carassius auratus gibelio - The most successeful invasive fish in waters of the Czech Republic. - Russian Journal of Biological Invasions 1 (3): 176-180.

Mlíkovský J. \& Stýblo P. (eds) (2006): Nepůvodní druhy fauny a flóry ČR (Alien fauna and flora species in the Czech Republic) Praha, ČSOP, 496 pp.

Musil J., Jurajda P., Adámek Z., Horký P. \& Slavík O. (2010): Non-native fish introductions in the Czech Republic - species inventory, facts and future perspectives. - J. Appl. Ichthyol. (Suppl. 2): 38-45.

Nehring S. \& Steinhof J. (2015): First records of the invasive Amur sleeper, Perccottus glenii Dybowski, 1877 in German freshwaters: a need for ralization of effective management (Suppl. 2): measures to stop the invasion. - Bioinvasions Records 4 (3): 223-232.

Papoušek I., Vetešník L., Halačka K., Lusková V., Humpl M. \& Mendel J. (2008): Identification of natural hybrids of gibel carp Carassius carassius gibelio (Bloch) and crucian carp Carassius carassius (L.) from lower Fyje River floodplain (Czech Republic). - J. Fish Biol. 72: 1230-1235.

Pechar L., Musil M., Baxa M., Petrů A., Benedová Z., Kropfelová L. \& Šulcová J. (2017): Tři roky bez kapra na rybníce Rod (Třeboňsko) - aneb, jak reálná je možnost zlepšit kvalitu vody a stav rybničního biotopu absencí obsádky kapra? (Three years without carps in the fishpond Rod (the region of Třeboň) - or, how realstic is the chance to improve water quality and the pond biotope situation by the absence of carps?) - Sb. ref. 4. odborné konference, Č. Budějovice, Rybářské sdružení ČR, pp. 55-59.

Pergl J., Sádlo J., Petrusek A., Laštůvka Z., Musil J., Perglová I., Šanda R., Šefrová H., Šíma J., Vohralík V.\& Pyšek P. (2016): Black, Grey and Watch Lists of alien species in the Czech Republic based on environmental impacts and management strategy. - NeoBiota 28: 1-37.

Prášek V. \& Jurajda P. (2005): Expansion pf Proterorhius marmoratus in the Morava River basin (Czech Republic, Danube R. watershed). - Folia Zool. 54: 189-192.

Reshetnikov A.N. (2004): The fish Perccottus glenii: history of introduction to western regions of Euroasia. Hydrobiologia 522: 349-350.

Roche K., Janáč M., Šlapanský L., Mikl L., Kopeček L. \& Jurajda P. (2015): A newly established round goby (Neogobius melanostomus) population in the upper stretch of the river Elbe. - Knowl. Manag. Aquat. Ecosyst. 416, art.num. 33, 11 pp.

Spindler T., Holčík J. \& Hensel K. (1992): Die Fischfauna der osterreichisch-tschechoslowakischen Grenztrecken der March sam ihrem Einzugsgebiet. Berich 5/1992, Forschungsinstitut WWF Osterrech, 179 pp.

Šanda R. (2006): Actinopterygii - Paprskoploutví. In Mlíkovský J. \& Stýblo P. (eds.): Nepůvodní druhy fauny a flóry České republiky (Non-native fauna and flora species in the Czech Republic) ČSOP, Praha, pp.368-398.

Šanda R. \& Švátora M. (2002): Ichtyofauna tří nejvýše položených nádrží Jizerských hor a jejich povodí (The ichthyofauna in the free highest located reservoirs in Jizerské Mts. and their catchments) - Biodiverzita ichtyofauny ČR (IV): 151-154.

Šefrová H. \& Laštůvka Z. (2005): Catalogue of alien animal species in the Czech Republic. - Acta univ. agric. et silvic. Mendel. Brun., LIII, No. 4: 151-170.

Welcomme R.L. (1988): International introductions of inland aquatic species. FAO Rome, 318 pp.

Williams on M. (1999): Invasions. - Ecography 22 (1): 5-12.

Witkowski A. (2002): Introduction of fishes into Poland: benefaction or plague? - Nature Conserv. 59: 51-52.

Wohlgemuth E. (1989): Výskyt koljušky tříostné (Gasterosteus aculeatus) na Moravě (Occurrence of Gasterosteus aculeatus in Moravia) - Zprávy ÚSEB Brno: 91-92.

Wohlgemuth E. \& Š ebela M. (1987): Střevlička východní, nový prvek evropské ichtyofauny (Pseudorasbora parva - a newcomer in the European fauna) - Živa 35: 91-95. 
Wolter C. \& Rohr F. (2010): Distribution history of non-native freshwater fish species in Germeny: How invasive are they? - J.Appl.Ichthyol. 26 (Suppl. 2): 19-27.

\section{Legislature}

Act No. 114/1992 Coll.

Act No. 99/2004 Coll.

Act No. 254/2001 Coll.

Commission implementing regulation (EU) 2016/1141 of July 2016 adopting a list of invasive alien species of Union concern pursuant to Regulation (EU) No 1143/2014 of the European Parliament and of the Council.

Author's address: Bohumír Lojkásek, University of Ostrava, Faculty of Natural Science, Chittussiho 10, CZ-710 00 Ostrava, Czech Republic.

e-mail: Bohumir.lojkasek@osu.cz

Stanislav Lusk, Bohuslava Martinů 9, CZ-602 00 Brno, Czech Republic.

e-mail: luskst@seznam.cz 